Russia as a Network State 
This page intentionally left blank 


\section{Russia as a Network State}

\section{What Works in Russia When State Institutions Do Not?}

Edited by

Vadim Kononenko

Research Fellow, Finnish Institute of International Affairs, Helsinki, Finland

and

Arkady Moshes

Programme Director, Finnish Institute for International Affairs,

Helsinki, Finland 


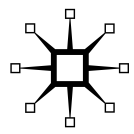

Introduction and conclusion (C) Vadim Kononenko 2011

Editorial matter and selection @ Vadim Kononenko and

Arkady Moshes 2011

All remaining chapters () respective authors 2011

Softcover reprint of the hardcover 1st edition 2011 978-0-230-24964-6

All rights reserved. No reproduction, copy or transmission of this publication may be made without written permission.

No portion of this publication may be reproduced, copied or transmitted save with written permission or in accordance with the provisions of the Copyright, Designs and Patents Act 1988, or under the terms of any licence permitting limited copying issued by the Copyright Licensing Agency, Saffron House, 6-10 Kirby Street, London EC1N 8TS.

Any person who does any unauthorized act in relation to this publication may be liable to criminal prosecution and civil claims for damages.

The authors have asserted their rights to be identified as the authors of this work in accordance with the Copyright, Designs and Patents Act 1988.

First published 2011 by

PALGRAVE MACMILLAN

Palgrave Macmillan in the UK is an imprint of Macmillan Publishers Limited, registered in England, company number 785998, of Houndmills, Basingstoke, Hampshire RG21 6XS.

Palgrave Macmillan in the US is a division of St Martin's Press LLC, 175 Fifth Avenue, New York, NY 10010.

Palgrave Macmillan is the global academic imprint of the above companies and has companies and representatives throughout the world.

Palgrave ${ }^{\circledR}$ and Macmillan ${ }^{\circledR}$ are registered trademarks in the United States, the United Kingdom, Europe and other countries.

ISBN 978-1-349-32083-7 ISBN 978-0-230-30670-7 (eBook)

DOI $10.1057 / 9780230306707$

This book is printed on paper suitable for recycling and made from fully managed and sustained forest sources. Logging, pulping and manufacturing processes are expected to conform to the environmental regulations of the country of origin.

A catalogue record for this book is available from the British Library.

Library of Congress Cataloging-in-Publication Data

Russia as a network state : what works in Russia when state

institutions do not? / edited by Vadim Kononenko, Arkady Moshes.

p. $\mathrm{cm}$.

Includes index.

1. Public administration-Russia (Federation) 2. Central-local government relations-Russia (Federation) 3. Local government-Russia (Federation)

4. Political culture-Russia (Federation) 5. Russia (Federation)—Politics and government. I. Kononenko, Vadim. II. Moshes, Arkadii. III. Title.

JN6695.R863 2011

302.30947-dc22

2011001648

$\begin{array}{llllllllll}10 & 9 & 8 & 7 & 6 & 5 & 4 & 3 & 2 & 1\end{array}$

$\begin{array}{llllllllll}20 & 19 & 18 & 17 & 16 & 15 & 14 & 13 & 12 & 11\end{array}$ 


\section{Contents}

List of Tables vi

Acknowledgements vii

Notes on Contributors viii

Introduction 1

Vadim Kononenko

1 The Formation of Russia's Network Directorate 19 Olga Kryshtanovskaya and Stephen White

2 Can Medvedev Change Sistema? Informal Networks and Public Administration in Russia 39 Alena Ledeneva

3 Crooked Hierarchy and Reshuffled Networks: Reforming Russia's Dysfunctional Military Machine Pavel Baev

4 Who is Running Russia's Regions? Nikolay Petrov

5 Networks, Cronies and Business Plans: Business-State Relations in Russia Philip Hanson

6 The Russian Network State as a Great Power Stefanie Ortmann

7 Conclusions

Vadim Kononenko

Select Bibliography 


\section{List of Tables}

1.1 List A Companies (in which key decisions are agreed with the Russian government)

1.2 Sectoral distribution of key state companies 30

1.3 Officials on the boards of major state companies, c. 201031

1.4 Elite groups on the boards of key state companies 32

1.5 Share of elite groups on the boards of state companies 33

4.1 Governors' appointments in 2005-10 by years 97 


\section{Acknowledgements}

The first stage in the compilation of this book was funded by the Friedrich Ebert Stiftung, which made it possible to conduct an expert round-table seminar on Russia's network governance, an occasion which also gave the authors the opportunity to discuss the contents of the book, in Helsinki in October 2008. The editors are grateful for the 'seed money', which was well received. Our gratitude is due to all the participants of the seminar: Prof. Stephen White, Prof. Alena Ledeneva, Dr Nikolay Petrov, Prof. Marie Mendras, Dr Susan Stewart, Dr Pavel Baev, Prof. Riitta Kosonen and Dr Uwe Optenhögel for their active personal involvement and interest in the subject of the book. The comments and criticism we received during the round-table seminar were immensely helpful in exploring the concept of the 'network state' and Russia. We are grateful to the authors who agreed to contribute chapters to this volume and who were enthusiastic enough to incorporate the new idea of the Russian network state into their scholarship and expertise.

The book was prepared in the Finnish Institute of International Affairs (FIIA), where both editors had been working for several years before embarking on this project. The editors are grateful to FIIA directors Prof. Raimo Väyrynen and Dr Teija Tiilikainen for their support, understanding and continuous encouragement for the project. Particular thanks are due to the administrative staff of the FIIA for their efficiency in taking care of all the administrative matters, and especially to research assistants Maija Hyypiä and Minna-Mari Salminen. Lynn Nikkanen deserves special thanks for painstakingly correcting the English language of the manuscript.

Our greatest thanks go to our families and friends who are undoubtedly the best and most endearing network that each of us would ever wish to engage with. We would like to extend our gratitude to Liz Blackmore and Shankar Narayanan for professional handling of editorial matters at Palgrave Macmillan. 


\section{Notes on Contributors}

Pavel Baev is Senior Researcher in the International Peace Research Institute, Oslo (PRIO). He is also Head of Working Group on International Dimensions of Civil Wars at the Centre for the Study of Civil War (CSCW) at PRIO. He graduated from Moscow State University (MA in Political Geography, 1979) and worked in a research institute in the USSR Ministry of Defence. After receiving a $\mathrm{PhD}$ in International Relations from the Institute of USA and Canada, Moscow in 1988, he worked in the Institute of Europe, Moscow until October 1992, when he joined PRIO. In 1995-2001 he was a co-editor of Security Dialogue, a quarterly policy-oriented journal produced at PRIO, and in 2000-4 he was Head of the Foreign and Security Policies program. He held a NATO Democratic Institutions Fellowship in 1994-6.

Philip Hanson is the author of The Rise and Fall of the Soviet Economy (2003) and co-editor of Regional Economic Change in Russia, Alexander Zinoviev as Writer and Thinker and Transformation From Below. He is a consultant on the Russian and Baltic economies for the Economist Intelligence Unit and Oxford Analytica, and an Associate Fellow of the Royal Institute of International Affairs Russia and Eurasia Programme.

Vadim Kononenko is Research Fellow at the FIIA. He was educated at St Petersburg State University and London School of Economics. His research interests include Russia's foreign policy and relations with the EU. He is a member of St Antony's College of the University of Oxford where he is conducting research on the role of public/ private networks in the making of Russia's energy policy.

Olga Kryshtanovskaya is Director of the Institute for Applied Political Science and the Head of the Department for the Study of Hierarchical Elites, which is a part of the Sociology Institute of the Russian Academy of Sciences. She holds an honorary professorship at the University of Glasgow. She has conducted research at universities in New York, Salzburg, and under contract to the French Ministry 
of Defence. She has been a 'spin doctor' for such politicians as Gorbachev, Chernomyrdin, Nemtsov and Lebed. She has likewise worked on the President's staff and for the Duma. In addition to numerous academic publications in international journals, she has also written political commentaries for such influential Russian newspapers as Moscow News, Argumenty $i$ fakty, Izvestiya and Vedomosti. Kryshtanovskaya came to international prominence with the publication of her essay 'The Russian Financial Oligarchy' in 1994.

Alena Ledeneva is Reader in Russian Politics and Society at the School of Slavonic and East European Studies, University College London. Her expertise is in post-Soviet Russian affairs: Russia in the global order, the Russian state and the rise of organized crime, barter economy, social networks and patron-client relationships. Prof. Ledeneva studied Economics at the Novosibirsk State University (1986) and Social and Political Theory at the University of Cambridge (MPhil 1992; PhD 1996). Until 1999, she was Research Fellow at New Hall, Cambridge.

Arkady Moshes is Programme Director of the Russia in the Regional and Global Context Programme of the FIIA. He has authored numerous academic articles and policy advice-oriented reports on Russia-EU relations, as well as specifically on Ukraine, Russia and Belarus.

Stefanie Ortmann is currently Lecturer in International Relations at the University of Sussex. Previously she was a lecturer at Royal Holloway, University of London and a visiting lecturer in the American University of Central Asia, Bishkek. She was awarded her PhD at the London School of Economics. Her research interests include the concept of identity in IR and the state in constructivist and critical IR theory. She explores these through analyses of Russian foreign policy, the international dimension of Russian state-building and 'normative competition' between Russia and the West.

Nikolay Petrov is Scholar-in-Residence at Carnegie Moscow Centre. He has served as chief organizer of the Analysis and Forecast Division in the Supreme Soviet (1991-2), advisor and analyst for the Russian Presidential Administration (1994-5), and scholar at the Kennan Institute for Advanced Russian Studies (1993-4) and the International Foundation for Electoral Systems (1994). He has been working at the Carnegie Moscow Center since 1996 with a break in 2000-2 when he lectured at Macalester College in the United States. 
Petrov earned his PhD from Moscow State University. His research interests include Russian domestic politics, regional development, civil society and elections.

Stephen White is James Bryce Professor of Politics and Senior Research Associate of the University of Glasgow's School of Central and East European Studies. He graduated from Trinity College Dublin in history and political science, and then completed a PhD in Soviet studies at Glasgow - including an exchange year at Moscow State University - and a DPhil in politics at Wolfson College Oxford. His research interests focus on Soviet and post-Soviet politics, with special emphasis on elections, voting and nonvoting, parties, political elites, public opinion and the media. He also works on the current politics and foreign policy of Belarus and Ukraine, on Russian foreign policy and political graphics. He was elected a Fellow of the British Academy in 2010. 